UDC 336.341:631

JEL Classification: F10

DOI: $10.15587 / 2312-8372.2019 .176665$

\title{
Kosata I. \\ IMPLEMENTATION OF ACCOUNTING IN THE SYSTEM OF INTEGRATED BUSINESS STRUCTURES
}

Об’єктом дослідження є євроінтеграція украйнського бухгалтерського обліку. Одним з найбільи проблемних місиь є недостатня відповідність українського бухгалтерського обліку світовим стандартам, яка перешкоджає інтеграиії України у світовий фінансовий простір.

У ході дослідження використовувалися методи емпіричного дослідження (спостереження, порівняння, узагальнення), методи теоретичного дослідження та аналітичний метод.

У роботі детально розглянуто розбіжності між Положенням (стандартом) бухгалтерського обліку України та Міжнародними стандартами фінансової звітності та бухгалтерського обліку інших держав. Ці розбіжності створюють суттєві перешкоди для ведення бізнесу та перешкоджають впровадженню бухгалтерського обліку в систему інтегрованих структур бізнесу. Обгрунтовано необхідність приведення державного бухгалтерського обліку та основних приниипів його побудови до міжнародних стандартів. Це необхідно для коректного впровадження в систему інтеграиійних структур бізнесу з метою забезпечення його ефективного функиіонування та набуття вагомих конкурентних переваг у сучасному ринковому середовищі. Зміни в бухгалтерському обліку мають спричинити зміни в податковому й цивільному законодавствах, оскільки перехід українського обліку на міжнародні стандарти стане важливою ланкою інтеграції української економіки в європейське та світове господарство.

Задля обтрунтування необхідності приведення державного бухгалтерського обліку та основних приниипів його побудови до міжнародних стандартів автором запропоновано такі кроки вирішення зазначеної проблеми:

- приведення у відповідність Положення (стандарту) бухгалтерського обліку Украӥни до Міжнародних стандартів фінансової звітності та бухгалтерського обліку інших держав;

- забезпечення адекватного тлумачення та дотримання норм Положення (стандарту) бухгалтерського обліку України;

- отримання аудиторського висновку щодо відповідності фінансової звітності вимогам Міжнародних стандартів фінансової звітності та бухгалтерського обліку інших держав.

Ключові слова: державний бухгалтерський облік, інтегровані структури бізнесу, міжнародні стандарти.

\section{Introduction}

Many scientists and economists have been and continue to be involved in determining the role and place of accounting in the system of integrated business structures, as well as methods for assessing their competitiveness, for example, in [1-3]. A detailed comparative analysis of the national regulations (standards) of accounting in Ukraine with international accounting standards was given by the author of the work [4]. This problem is also reflected in [5-7]. The attention of the authors of these works is focused on the spread of integration processes in society and is currently being discussed in many modern studies. As indicated in [7, 8], the issue of the lack of a unified accounting system in various countries creates serious difficulties for global integration.

Based on the analysis of the mentioned works, it can be concluded that the spread of integration processes in society and their impact on the country's competitiveness are relevant, as well as the need to introduce international financial reporting standards.
So, the object of research is the European integration of Ukrainian accounting. The aim of research is justification of the need to bring public accounting and the basic principles of its construction with international standards.

\section{Methods of research}

The study used:

- methods of empirical research (observation, comparison, generalization), with the help of which general and diverging aspects between accounting in Ukraine and international standards were discovered and analyzed. The consequences of such disagreements on the implementation of accounting in the system of integrated business structures were also identified;

- methods of theoretical research. Using these methods, a detailed comparative analysis of the national accounting regulations (standards) of Ukraine with international accounting standards was carried out. Also, the scientific works of modern leading scientists 
and the accounting legislation of Ukraine and other countries of the world were analyzed;

- an analytical method that allowed to draw conclusions on solving the problems indicated in the work.

\section{Research results and discussion}

Integration of production and concentration of capital occurs by creating large multi-level structures with various principles, a combination of economically dependent or fully independent business entities. At present, when Ukraine is actively involved in the global processes of globalization, it is necessary to take into account such problems as economic, military, environmental, cultural, informational, etc. Moreover, it is necessary to find ways to solve the main problem: improving the level and quality of life of the population of Ukraine. In the formation and development of integrated business structures, which, in turn, determine the competitiveness of a business through its activities, accounting plays a key role. It is, as indicated in $[9,10]$, «conducted at the enterprise from the moment of its creation to the moment of its liquidation and does not depend on the organizational form and form of ownership». The integration of Ukraine into the economic space of the world community makes it possible to eliminate existing economic barriers, as well as Ukrainian producers and goods to be in a competitive environment among manufacturers and goods at the European level and markets. It should be noted that accounting in Ukraine, which is regulated by the National Provision (Standard) of Accounting $(\mathrm{P}(\mathrm{S}) \mathrm{A})$, differs significantly from International Financial Reporting and Accounting Standards of other countries (IFRS/IAS). This makes it difficult to conduct business operations at the international level and determines the prospects of this research.

The differences between $\mathrm{P}(\mathrm{S}) \mathrm{A}$ and IFRS/IAS are given in Table 1.

Table 1

Disagreements between the Provision (5tandard) of accounting (P(S)A) and International Financial Reporting Standards and accounting (IFR5/IAS)

\begin{tabular}{|l|l|l|}
\hline \multicolumn{1}{|c|}{ Criterion } & \multicolumn{1}{|c|}{ P(S)A } & \multicolumn{1}{c|}{ IFRS/IAS } \\
\hline $\begin{array}{l}\text { Financial reporting } \\
\text { format }\end{array}$ & $\begin{array}{l}\text { Standard forms appro- } \\
\text { ved by the Ministry of } \\
\text { Finance are regulated }\end{array}$ & Report format not regulated \\
\hline Types of reporting & $\begin{array}{l}\text { Consolidated and indi- } \\
\text { vidual }\end{array}$ & $\begin{array}{l}\text { Consolidated, separate and } \\
\text { individual }\end{array}$ \\
\hline $\begin{array}{l}\text { Reporting for a small } \\
\text { business }\end{array}$ & $\begin{array}{l}\text { Limits the reporting of } \\
\text { small businesses to bal- } \\
\text { ance sheet, statement of } \\
\text { financial results }\end{array}$ & $\begin{array}{l}\text { It is required from subjects } \\
\text { of medium and small busi- } \\
\text { ness to prepare all types } \\
\text { of reports }\end{array}$ \\
\hline Notes & $\begin{array}{l}\text { Served in the format spe- } \\
\text { cified by the Ministry of } \\
\text { Finance. } \\
\text { Links to notes in reports } \\
\text { are not required. } \\
\text { Comparative information } \\
\text { is not provided }\end{array}$ & $\begin{array}{l}\text { Free form. } \\
\text { Link to notes in reports } \\
\text { needed. } \\
\text { Comparative information } \\
\text { for the previous period is } \\
\text { provided }\end{array}$ \\
\hline
\end{tabular}

As can be seen from the Table 1, there is currently a good reason for Ukraine moving to international accounting standards. This will allow for harmonization of accounting information with both national and international requirements. It will also help prevent complications in working with investors, lenders and other users.
In connection with the further spread of the introduction of international accounting standards at Ukrainian enterprises, there is an urgent need for a complete change in the traditional attitude to financial information. Effective work at the present stage is impossible without a wellfunctioning system of accounting and reporting at all levels.

Currently, Ukraine is in the midst of a systematic restructuring of the economy in the direction of its adaptation to world standards. Objectively, it is necessary to create transparent mechanisms of interaction that would stimulate an increase in the effectiveness of the form of organization of entrepreneurial activity in order to maximize the well-being of owners and harmonize relations in the system of integrated business structures.

It should be noted that such specific factors are inherent in modern business:

- a constant increase in capital concentration;

- high level of competition;

- a significant increase in production costs;

- unpredictability of inflationary movements (even in financially stable countries), etc.

For any accounting situation in the country, there must be a set of standards. The standardization of accounting implies the establishment of uniform standards and requirements for accounting. Accounting standardization depends on the underlying concept on which it is based. First of all, these are principles or rules. Accounting principles must meet three criteria:

1) relevance;

2) objectivity;

3) implementation.

Modern society is developing, along with this, accounting is developing. The development of modern accounting is associated with the globalization of the economy. Accounting in Ukraine must undergo adjustments and changes, accept compliance with international standards.

Changes in accounting should result in changes in tax and civil law. The transition of Ukrainian accounting to international standards will become an important link in the integration of the Ukrainian economy into European and world economy.

All this requires the competent implementation of changes in accounting in the system of integrated business structures. The presence of disagreements between the provisions (standards) of accounting and international standards significantly affects the value of financial statements and the quality of information received. This may cause some distrust among international investors, and therefore hinder the conduct of business. Therefore, we consider it necessary to propose such steps to solve this problem:

- bringing the norms of national standards into line with the provisions of IFRS;

- ensuring adequate interpretation and compliance with the $\mathrm{P}(\mathrm{S}) \mathrm{A}$ norms;

- obtaining an audit opinion on the compliance of the financial statements with the IFRS requirements.

\section{Conclusions}

So, based on the foregoing, it is possible to conclude that lately, integrated business structures have become increasingly important in the development of the global economy. It is proved in the work that the transition of Ukrainian accounting to international standards will become an important link in 
the integration of the Ukrainian economy into European and world economy. It is substantiated that accounting in Ukraine should undergo adjustments and changes, accept compliance with international standards. It also noted the need for the implementation of accounting and the basic principles of its construction in the system of standards of integrated business structures. It is proved that accounting is an influential tool that creates the conditions for the acquisition of significant competitive advantages in a modern market environment.

\section{References}

1. Kyzym, M. O., Ponomarenko, V. S., Horbatov, V. M. et. al. (2010). Intehrovani struktury biznesu: problemy teorii ta praktyky otsiniuvannia konkurentospromozhnosti. Kharkiv: VD «INZhEK», 368

2. Marchenko, V. M. (2011). Metodychni pidkhody do otsiniuvannia synerhetychnoho efektu zlyttia i pohlynannia. Aktualni problemy ekonomiky, 4 (118), 135-142.

3. Nifatova, O. M. (2017). Benchmarkinh intehrovanykh struktur biznesu. Problemy ekonomiky, 2, 217-222.

4. Khill, B. (2010). Porivniannia natsionalnykh polozhen (standartiv) bukhhalterskoho obliku Ukrainy z mizhnarodnymy standartamy bukhhalterskoho obliku: prohrama finansovoho navchannia. Kyiv: Proekt USAID «Rozvytokrynkiv kapitalu», 37.
5. Golikova, Iu. A. (2011). Metakorporacii: priroda ikh obrazovaniia i rol v sovremennoi mirovoi ekonomike. Korporativnye finansy, 2 (18), 33-42.

6. Mescheriakov, S. G. (2013). Osnovnye ekonomicheskie pokazateli $i$ metody ocenki effektionosti deiatelnosti kholdinga. Available at: http://www.cfin.ru/bandurin/article/sbrn03/

7. Knights, D., Tullberg, M. (2011). Managing masculinity/mismanaging the corporation. Organization, 19 (4), 385-404. doi: http:// doi.org/10.1177/1350508411408170

8. Sudyn, Yu. (2013). Porivnialnyi analiz MSFZ ta P(S)BO zahalnyi analiz do finansovoi zvitnosti. Nauka moloda, 19 207-212. Available at: http://naukamolodaj.tneu.edu.ua/index. $\mathrm{php} / \mathrm{nmj} /$ article/view/72

9. Pro bukhhalterskyi oblik ta finansozu zvitnist v Ukraini (1999) Zakon Ukrainy No. 996-XIV. 16.07.1999. Available at: http:// zakon5.rada.gov.ua/laws/show/996-14

10. Natsionalni polozhennia (standarty) bukhhalterskoho obliku. Available at: http://vobu.ua/ukr/documents/accounting/item/ natsionalni-polozhennya-standarti-bukhgalterskogo-obliku? app_id $=24$

Kosata Inna, PhD, Associate Professor, Department of Statistics, Accounting and Auditing, V. N. Karazin Kharkiv National University, Ukraine, e-mail: ikosata@karazin.ua, ORCID: http://orcid.org/ 0000-0002-7690-137 